Nevada

Environmental

Restoration

Project

Corrective Action Plan for

Corrective Action Unit 562:

Waste Systems,

Nevada National Security Site,

Nevada

Controlled Copy No::

Revision: 0

April 2011

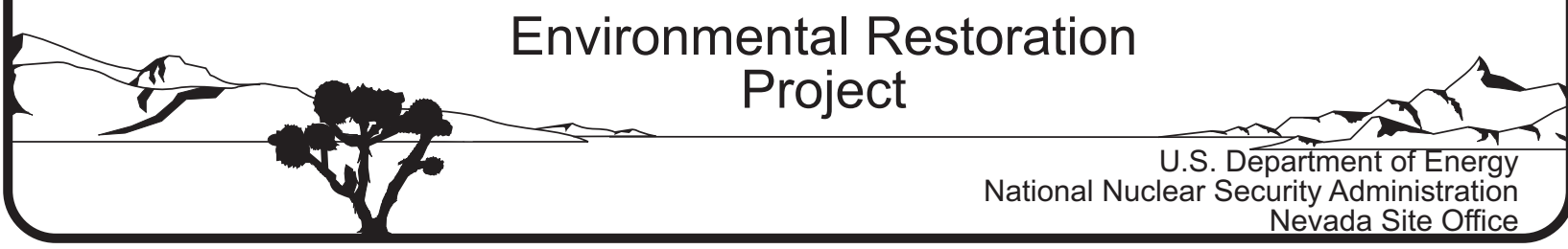




\title{
DISCLAIMER
}

Reference herein to any specific commercial product, process, or service by trade name, trademark, manufacturer, or otherwise, does not necessarily constitute or imply its endorsement, recommendation, or favoring by the U.S. Government or any agency thereof.

This report has been reproduced directly from the best available copy.

Available for sale to the public from:

\author{
U.S. Department of Commerce \\ National Technical Information Service \\ 5301 Shawnee Road \\ Alexandria, VA 22312 \\ Telephone: (800) 553-6847 \\ Fax: (703) 605-6900 \\ E-mail: orders@ntis.gov \\ Online ordering: http://www.ntis.gov/help/ordermethods.aspx
}

Available electronically at http://www.osti.gov/bridge.

Available for a processing fee to the U.S. Department of Energy and its contractors, in paper, from:

U.S. Department of Energy

Office of Scientific and Technical Information

P.O. Box 62

Oak Ridge, TN 37831-0062

Telephone: (865) 576-8401

Fax: (865) 576-5728

E-mail: reports@adonis.osti.gov 


\title{
CORRECTIVE ACTION PLAN FOR CORRECTIVE ACTION UNIT 562: WASTE SYSTEMS, NEVADA NATIONAL SECURITY SITE, NEVADA
}

\author{
U.S. Department of Energy \\ National Nuclear Security Administration \\ Nevada Site Office \\ Las Vegas, Nevada
}

Controlled Copy No.

Revision: 0

April 2011 
THIS PAGE INTENTIONALLY LEFT BLANK 


\section{CORRECTIVE ACTION PLAN FOR CORRECTIVE ACTION UNIT 562: WASTE SYSTEMS, NEVADA NATIONAL SECURITY SITE, NEVADA}

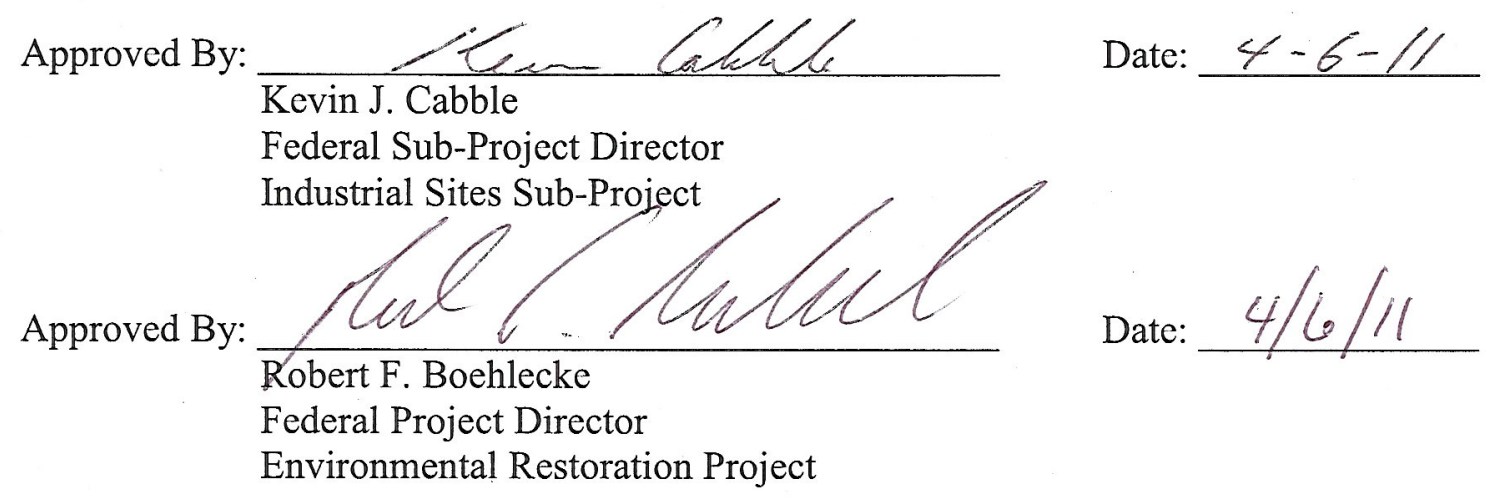


THIS PAGE INTENTIONALLY LEFT BLANK 
ACRONYMS AND ABBREVIATIONS .......................................................................................

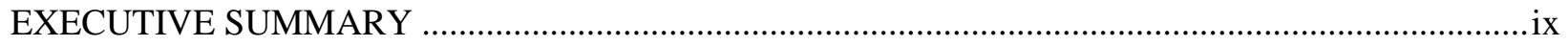

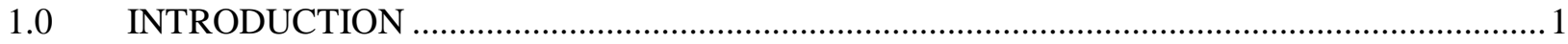

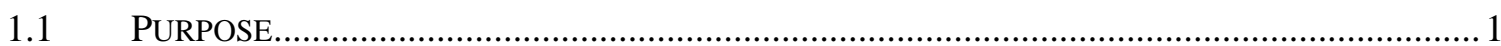

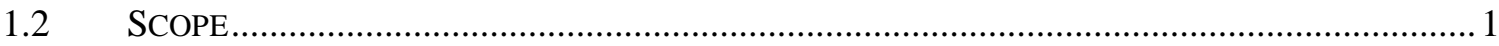

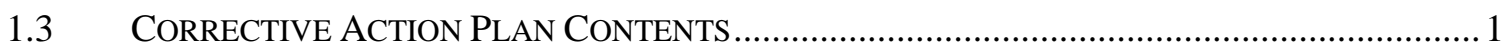

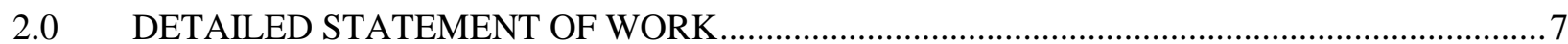

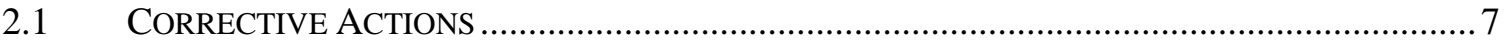

2.1.1 Alternative 1, No Further Action....................................................................... 7

2.1.1.1 Corrective Action Site 02-60-01, Concrete Drain ............................... 7

2.1.1.2 Corrective Action Site 02-60-06, French Drain .................................. 7

2.1.1.3 Corrective Action Site 02-60-07, French Drain .................................. 7

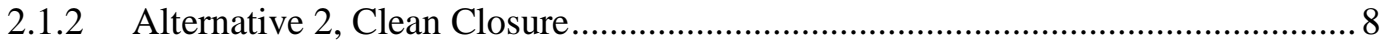

2.1.2.1 Corrective Action Site 02-26-11, Lead Shot ....................................... 8

2.1.2.2 Corrective Action Site 02-44-02, Paint Spills and French Drain........ 8

2.1.2.3 Corrective Action Site 02-59-01, Septic System .................................. 9

2.1.2.4 Corrective Action Site 02-60-02, French Drain .................................... 9

2.1.2.5 Corrective Action Site 02-60-03, Steam Cleaning Drain ..................... 9

2.1.2.6 Corrective Action Site 02-60-04, French Drain ................................. 10

2.1.2.7 Corrective Action Site 02-60-05, French Drain ................................ 10

2.1.2.8 Corrective Action Site 23-60-01, Mud Trap Drain and Outfall ........ 10

2.1.2.9 Corrective Action Site 23-99-06, Grease Trap................................... 11

2.1.2.10 Corrective Action Site 25-60-04, Building 3123 Outfalls ..................11

2.2 CONSTRUCTION QUALITY ASSURANCE/QUALITY CONTROL ....................................... 11

2.2.1 Construction Field Sample Collection Activities ................................................ 11

2.2.2 Construction Laboratory/Analytical Data Quality Indicators ............................... 11

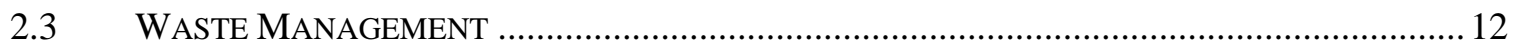

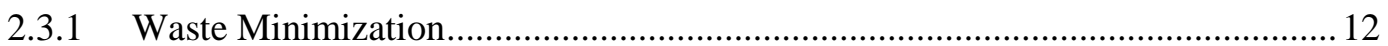

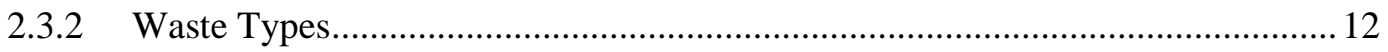

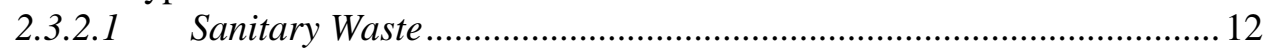

2.3.2.2 Mixed Waste .................................................................................... 12

2.3.2.3 Hazardous Waste ...................................................................... 12

2.3.2.4 Low-Level Waste ........................................................................... 12

2.3.2.5 Decontamination Waste ..................................................................... 13

2.3.2.6 Personal Protective Equipment ...................................................... 13

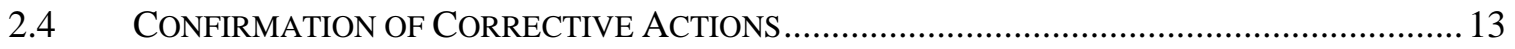

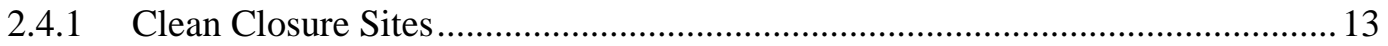

2.4.1.1 Corrective Action Site 02-26-11, Lead Shot ..................................... 13

2.4.1.2 Corrective Action Site 02-44-02, Paint Spills and French Drain...... 13

2.4.1.3 Corrective Action Site 02-59-01, Septic System ................................ 14

2.4.1.4 Corrective Action Site 02-60-02, French Drain ................................. 14

2.4.1.5 Corrective Action Site 02-60-03, Steam Cleaning Drain ................... 14

2.4.1.6 Corrective Action Site 02-60-04, French Drain .................................. 14

2.4.1.7 Corrective Action Site 02-60-05, French Drain ................................. 14

2.4.1.8 Corrective Action Site 23-60-01, Mud Trap Drain and Outfall .........14

2.4.1.9 Corrective Action Site 23-99-06, Grease Trap................................. 14

2.4.1.10 Corrective Action Site 25-60-04, Building 3123 Outfalls .................. 14 


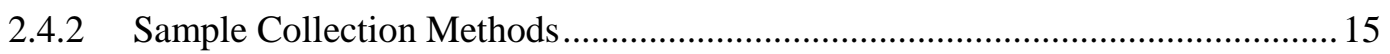

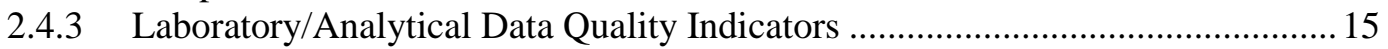

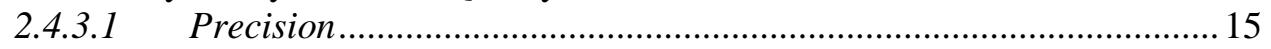

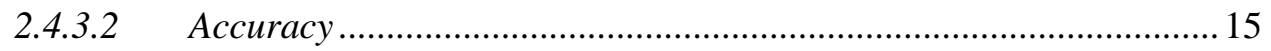

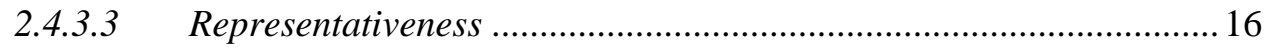

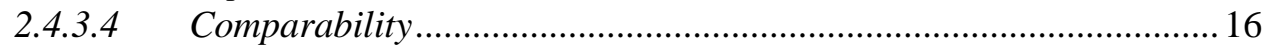

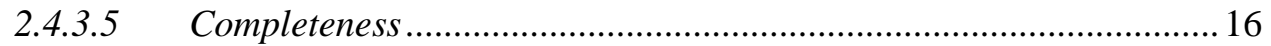

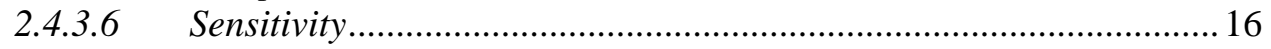

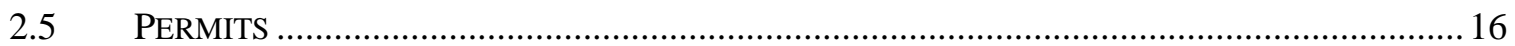

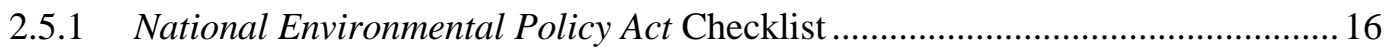

2.5.2 Real Estate/Operations Permit ............................................................................. 16

2.5.3 Radiological Work Permit ................................................................................. 17

2.5.4 Utility Clearances, Excavation Permits, and Blind Penetration Permits .............. 17

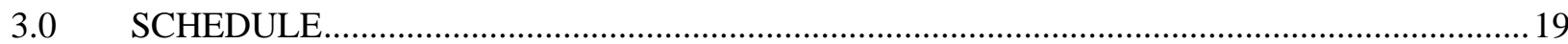

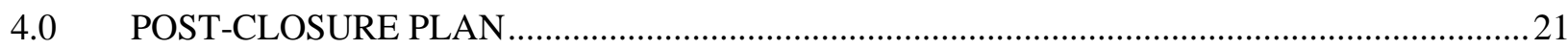

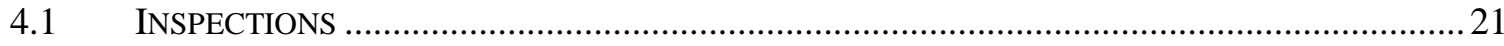

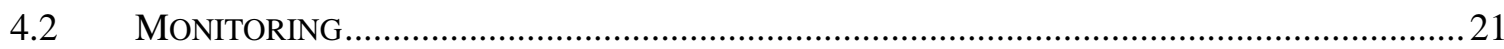

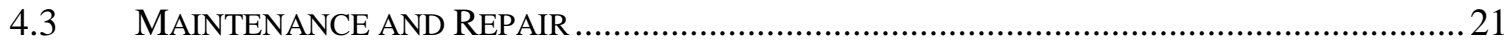

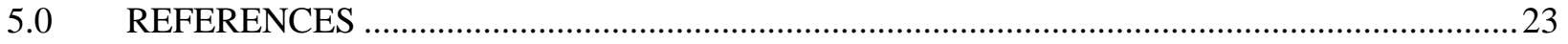

LIBRARY DISTRIBUTION LIST

\section{LIST OF FIGURES}

Figure 1. Corrective Action Unit 562 Site Location MaP ............................................... 3

\section{LIST OF TABLES}

TABle 1. Corrective Action Unit 562 Closure Activities ................................................ 4

TABle 2. Verification SAMPle MethodS AND Action LEVELS ........................................... 13

\section{LIST OF APPENDICES}

APPENDIX A.1. ENGINEERING SPECIFICATIONS AND DRAWINGS ......................................... A.1-1

APPENDIX A.2. SAMPLING AND ANALYSIS PLAN ............................................................... A.2-1

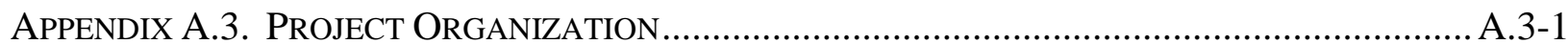




\section{ACRONYMS AND ABBREVIATIONS}

BMP

bgs

CADD

CAP

CAS

CAU

COC

CR

EPA

$\mathrm{ft}$

gal

HW

in.

LLW

$\mathrm{mg} / \mathrm{kg}$

MW

NNSA/NSO

NNSA/NV

QA/QC

$\% \mathrm{R}$

RCRA

RPD

RWP

SVOC

$\mathrm{yd}^{3}$ best management practice

below ground surface

Corrective Action Decision Document

Corrective Action Plan

Corrective Action Site

Corrective Action Unit

contaminant of concern

Closure Report

U.S. Environmental Protection Agency

foot (feet)

gallon(s)

hazardous waste

inch(es)

low-level waste

milligram(s) per kilogram

mixed waste

U.S. Department of Energy, National Nuclear Security Administration Nevada Site Office

U.S. Department of Energy, National Nuclear Security Administration Nevada Operations Office

quality assurance/quality control

percent recovery

Resource Conservation and Recovery Act

relative percentage difference

Radiological Work Permit

semi-volatile organic compound

cubic yard(s) 
CAU 562 CAP

Section: Acronyms and Abbr.

Revision: 0

Date: April 2011

THIS PAGE INTENTIONALLY LEFT BLANK 
This Corrective Action Plan has been prepared for Corrective Action Unit (CAU) 562, Waste Systems, in accordance with the Federal Facility Agreement and Consent Order (1996; as amended March 2010). CAU 562 consists of 13 Corrective Action Sites (CASs) located in Areas 2, 23, and 25 of the Nevada National Security Site.

Site characterization activities were performed in 2009 and 2010, and the results are presented in Appendix A of the Corrective Action Decision Document for CAU 562 (U.S. Department of Energy, National Nuclear Security Administration Nevada Site Office, 2010). The scope of work required to implement the recommended closure alternatives is summarized below.

- CAS 02-26-11, Lead Shot, will be clean closed by removing shot.

- CAS 02-44-02, Paint Spills and French Drain, will be clean closed by removing paint and contaminated soil. As a best management practice (BMP), asbestos tile will be removed.

- CAS 02-59-01, Septic System, will be clean closed by removing septic tank contents. As a BMP, the septic tank will be removed.

- CAS 02-60-01, Concrete Drain, contains no contaminants of concern (COCs) above action levels. No further action is required; however, as a BMP, the concrete drain will be removed.

- CAS 02-60-02, French Drain, was clean closed. Corrective actions were completed during corrective action investigation activities. As a BMP, the drain grates and drain pipe will be removed.

- CAS 02-60-03, Steam Cleaning Drain, will be clean closed by removing contaminated soil. As a BMP, the steam cleaning sump grate and outfall pipe will be removed.

- CAS 02-60-04, French Drain, was clean closed. Corrective actions were completed during corrective action investigation activities.

- CAS 02-60-05, French Drain, will be clean closed by removing contaminated soil.

- CAS 02-60-06, French Drain, contains no COCs above action levels. No further action is required.

- CAS 02-60-07, French Drain, requires no further action. The french drain identified in historical documentation was not located during corrective action investigation activities.

- CAS 23-60-01, Mud Trap Drain and Outfall, will be clean closed by removing sediment from the mud trap. As a BMP, the mud trap and outfall pipe will be removed.

- CAS 23-99-06, Grease Trap, will be clean closed by removing sediment from the grease trap and backfilling the grease trap with grout.

- CAS 25-60-04, Building 3123 Outfalls, will be clean closed by removing contaminated soil and the sludge-containing outfall pipe. 
CAU 562 CAP

Section: Executive Summary

Revision: 0

Date: April 2011

\section{THIS PAGE INTENTIONALLY LEFT BLANK}




\subsection{INTRODUCTION}

This Corrective Action Plan (CAP) has been prepared in accordance with the Federal Facility Agreement and Consent Order (1996; as amended March 2010). Corrective Action Unit (CAU) 562, Waste Systems, is located in Areas 2, 23, and 25 of the Nevada National Security Site and consists of the following 13 Corrective Action Sites (CASs) (Figure 1):

- CAS 02-26-11, Lead Shot

- CAS 02-44-02, Paint Spills and French Drain

- CAS 02-59-01, Septic System

- CAS 02-60-01, Concrete Drain

- CAS 02-60-02, French Drain

- CAS 02-60-03, Steam Cleaning Drain

- CAS 02-60-04, French Drain

- CAS 02-60-05, French Drain

- CAS 02-60-06, French Drain

- CAS 02-60-07, French Drain

- CAS 23-60-01, Mud Trap Drain and Outfall

- CAS 23-99-06, Grease Trap

- CAS 25-60-04, Building 3123 Outfalls

\subsection{Purpose}

Site history and characterization results are provided in the Corrective Action Investigation Plan (U.S. Department of Energy, National Nuclear Security Administration Nevada Site Office [NNSA/NSO], 2009) and Corrective Action Decision Document (CADD) (NNSA/NSO, 2010). This CAP presents the scope of work required to implement the recommended corrective actions, as specified in Section 4.0 of the CADD (NNSA/NSO, 2010).

\subsection{SCOPE}

Closure activities include removal of contaminated materials and best management practices (BMPs). Table 1 presents CAS-specific closure activities and contaminants of concern (COCs). Details are presented in Section 2.0.

\subsection{Corrective Action Plan Contents}

This CAP consists of the following sections and appendices:

- Section 1.0: Introduction

- Section 2.0: Detailed Statement of Work

- Section 3.0: Schedule

- Section 4.0: Post-Closure Plan

- Section 5.0: References 
- Appendix A.1: Engineering Specifications and Drawings

- Appendix A.2: Sampling and Analysis Plan

- Appendix A.3: Project Organization

- Library Distribution List 


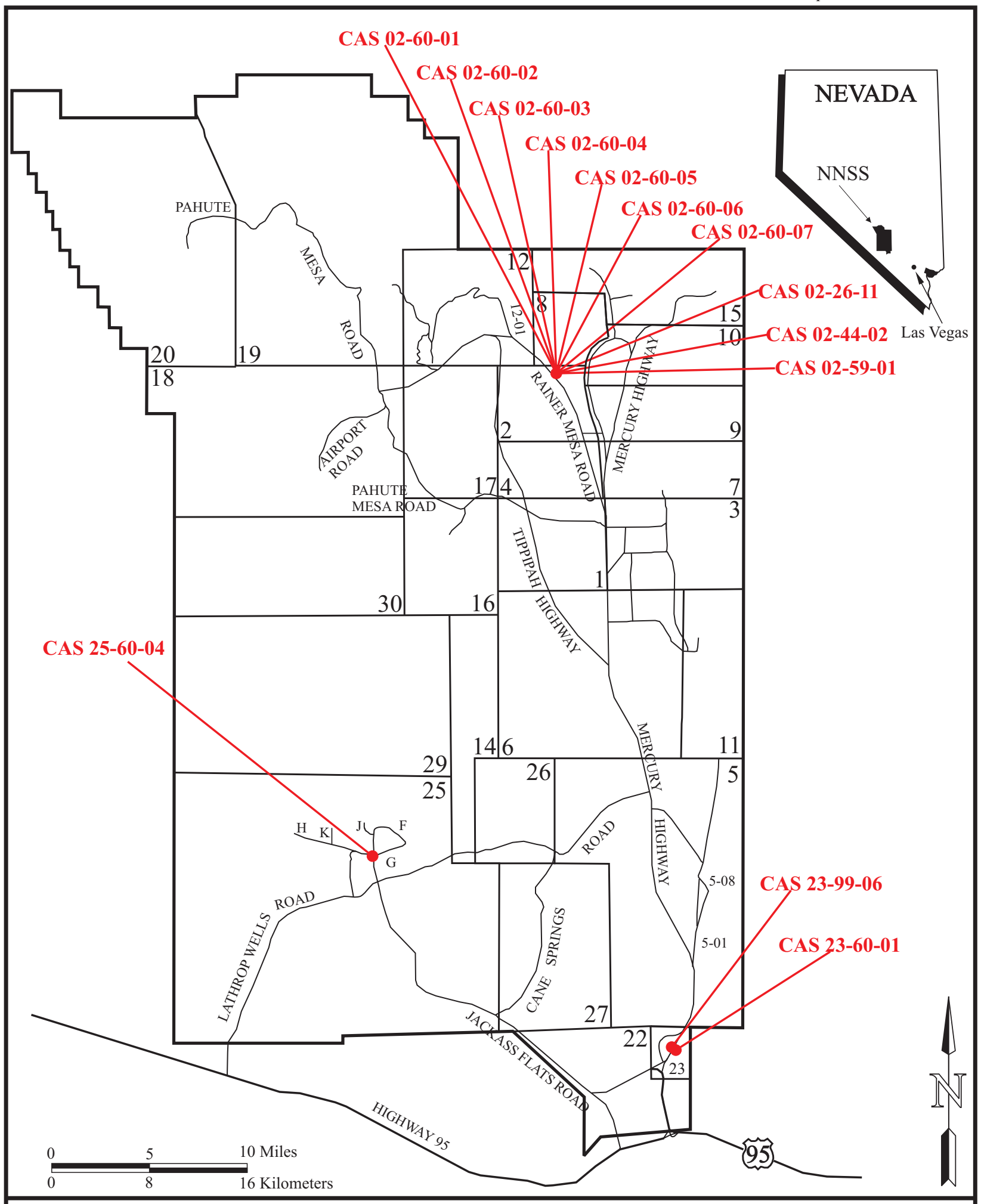

Figure 1. Corrective ACtion Unit 562 Site Location MaP 
Table 1. Corrective Action Unit 562 Closure Activities

\begin{tabular}{|c|c|c|c|c|}
\hline CAS & Name & Closure Method & COCs & Scope of Work \\
\hline 02-26-11 & Lead Shot & Clean Closure & $\begin{array}{l}\text { Lead } \\
\text { Antimony } \\
\text { Arsenic } \\
\text { Chromium } \\
\end{array}$ & $\begin{array}{l}\text { - Remove approximately } 2.5 \mathrm{yd}^{3} \text { of shot for disposal as HW and backfill } \\
\text { excavation }\end{array}$ \\
\hline 02-44-02 & $\begin{array}{l}\text { Paint Spills and } \\
\text { French Drain }\end{array}$ & Clean Closure & $\begin{array}{c}\text { Lead } \\
\text { Chromium } \\
\text { Benzo(a)pyrene } \\
\text { Benzo(b)fluoranthene } \\
\text { Bis(2-ethylhexyl)phthalate }\end{array}$ & $\begin{array}{l}\text { - Remove approximately } 55 \text { gal of dried paint from the foundations of } \\
\text { the former Paint Storage Rack and Painters' Shed for likely disposal as } \\
\text { HW } \\
\text { - Remove approximately } 2 \mathrm{yd}^{3} \text { of soil contaminated with benzo(a)pyrene } \\
\text { for likely disposal as HW, collect verification samples, and backfill } \\
\text { excavation } \\
\text { - As a BMP, remove asbestos tile }\end{array}$ \\
\hline 02-59-01 & Septic System & Clean Closure & $\begin{array}{l}\text { 1,4-dichlorobenzene } \\
\text { Naphthalene }\end{array}$ & $\begin{array}{l}\text { - Remove, solidify, and dispose approximately } 4,200 \text { gal of liquid and } \\
550 \text { gal of sludge from the septic tank as sanitary waste } \\
\text { - As a BMP, remove the septic tank and backfill excavation }\end{array}$ \\
\hline 02-60-01 & Concrete Drain & No Further Action & None & - As a BMP, remove the concrete drain \\
\hline 02-60-02 & French Drain & Clean Closure & Aroclor 1260 & $\begin{array}{l}\text { - Corrective actions were completed during corrective action } \\
\text { investigation activities. } \\
\text { - As a BMP, remove drain grates and drain pipe }\end{array}$ \\
\hline 02-60-03 & $\begin{array}{c}\text { Steam } \\
\text { Cleaning Drain }\end{array}$ & Clean Closure & $\begin{array}{l}\text { Aroclor } 1260 \\
\text { Benzo(a)pyrene }\end{array}$ & $\begin{array}{l}\text { - Remove approximately } 16 \mathrm{yd}^{3} \text { of soil contaminated with } \\
\text { benzo(a)pyrene for likely disposal as sanitary waste, collect verification } \\
\text { samples, and backfill excavation } \\
\text { - Remove approximately } 10 \mathrm{yd}^{3} \text { of soil contaminated with Aroclor } 1260 \\
\text { for likely disposal as } \mathrm{HW} \text {, collect verification samples, and backfill } \\
\text { excavation } \\
\text { - As a BMP, remove the steam cleaning sump grate and outfall pipe }\end{array}$ \\
\hline 02-60-04 & French Drain & Clean Closure & $\begin{array}{c}\text { Aroclor } 1260 \\
\text { Aroclor } 1268 \\
\text { Benzo(a)pyrene }\end{array}$ & $\begin{array}{l}\text { - Corrective actions were completed during corrective action } \\
\text { investigation activities. }\end{array}$ \\
\hline
\end{tabular}


TAble 1. Corrective ACtion Unit 562 Closure Activities (CONTINUED)

\begin{tabular}{|c|c|c|c|c|}
\hline CAS & Name & Closure Method & COCs & Scope of Work \\
\hline 02-60-05 & French Drain & Clean Closure & $\begin{array}{c}\text { Benzo(a)pyrene } \\
\text { Benzo(a)anthracene } \\
\text { Benzo(b)fluoranthene } \\
\text { Benzo(k)fluoranthene } \\
\text { Dibenzo(a,h)anthracene } \\
\text { Indeno(1,2,3-cd)pyrene } \\
\end{array}$ & $\begin{array}{l}\text { - Remove approximately } 48 \mathrm{yd}^{3} \text { of soil for disposal as sanitary waste, } \\
\text { collect verification samples, and backfill excavation }\end{array}$ \\
\hline $02-60-06$ & French Drain & No Further Action & None & - No corrective actions required \\
\hline 02-60-07 & French Drain & No Further Action & None & - No corrective actions required \\
\hline $23-60-01$ & $\begin{array}{l}\text { Mud Trap } \\
\text { Drain and } \\
\text { Outfall }\end{array}$ & Clean Closure & Lead & $\begin{array}{l}\text { - Remove approximately } 0.5 \mathrm{yd}^{3} \text { of sediment from the mud trap for } \\
\text { likely disposal as HW } \\
\text { - As a BMP, remove the mud trap and outfall pipe and backfill } \\
\text { excavation }\end{array}$ \\
\hline 23-99-06 & Grease Trap & Clean Closure & $\begin{array}{l}\text { Arsenic } \\
\text { Aroclor } 1260 \\
\text { Chlordane } \\
\end{array}$ & $\begin{array}{l}\text { - Remove approximately } 0.5 \mathrm{yd}^{3} \text { of sediment from the grease trap for } \\
\text { disposal as sanitary waste and backfill grease trap }\end{array}$ \\
\hline $25-60-04$ & $\begin{array}{l}\text { Building } 3123 \\
\text { Outfalls }\end{array}$ & Clean Closure & $\begin{array}{l}\text { Aroclor } 1254 \\
\quad \text { Lead }\end{array}$ & $\begin{array}{l}\text { - Remove outfall pipe and approximately } 0.25 \mathrm{yd}^{3} \text { of sludge } \\
\text { contaminated with lead and Aroclor } 1254 \text { for likely disposal as HW } \\
\text { - Remove approximately } 30 \mathrm{yd}^{3} \text { of soil contaminated with Aroclor } 1254 \\
\text { for disposal as sanitary waste, collect verification samples, and backfill } \\
\text { excavation }\end{array}$ \\
\hline
\end{tabular}

BMP: best management practice

CAS: Corrective Action Site

COC: contaminant of concern

gal: gallon(s)

HW: hazardous waste

$\mathrm{yd}^{3}$ : cubic yard(s) 
CAU 562 CAP

Section: Introduction

Revision: 0

Date: April 2011

THIS PAGE INTENTIONALLY LEFT BLANK 


\subsection{DETAILED STATEMENT OF WORK}

The approved corrective actions for CAU 562, as evaluated in Section 3.0 of the CADD and identified in Section 4.0 of the CADD (NNSA/NSO, 2010), include the following:

- CAS 02-26-11, Lead Shot: Clean Closure

- CAS 02-44-02, Paint Spills and French Drain: Clean Closure

- CAS 02-59-01, Septic System: Clean Closure

- CAS 02-60-01, Concrete Drain: No Further Action

- CAS 02-60-02, French Drain: Clean Closure

- CAS 02-60-03, Steam Cleaning Drain: Clean Closure

- CAS 02-60-04, French Drain: Clean Closure

- CAS 02-60-05, French Drain: Clean Closure

- CAS 02-60-06, French Drain: No Further Action

- CAS 02-60-07, French Drain: No Further Action

- CAS 23-60-01, Mud Trap Drain and Outfall: Clean Closure

- CAS 23-99-06, Grease Trap: Clean Closure

- CAS 25-60-04, Building 3123 Outfalls: Clean Closure

\subsection{CORRECTIVE ACTIONS}

The corrective action alternatives are identified in the CADD (NNSA/NSO, 2010) and were approved by the Nevada Division of Environmental Protection.

\subsubsection{Alternative 1, No Further Action}

\subsubsection{Corrective Action Site 02-60-01, Concrete Drain}

This site is located in Area 2 near the former Tank Farm and consists of a concrete drain approximately 4 by 2.5 feet (ft) and $1 \mathrm{ft}$ deep. No COCs were identified, and no further action is required. As a BMP, the concrete drain will be removed, and the excavation will be backfilled with clean soil and contoured to the approximate surrounding topographic grade.

\subsubsection{Corrective Action Site 02-60-06, French Drain}

This site is located in Area 2 at the former Electricians' Shop and consists of a french drain. No COCs were identified, and no further action is required.

\subsubsection{Corrective Action Site 02-60-07, French Drain}

The french drain identified in historical documentation was not located during corrective action investigation activities; therefore, it was concluded that there was an error in the historical document that identified this area as an environmental concern and that there is no french drain associated with the Electrical Supply Building. Therefore, no further action is required. 


\subsubsection{Alternative 2, Clean Closure}

\subsubsection{Corrective Action Site 02-26-11, Lead Shot}

This site is located in Area 2 near the former Laborers' Storage Area and consists of shot scattered throughout the area to a depth of up to $1 \mathrm{ft}$ below ground surface (bgs). Lead, antimony, arsenic, and chromium were identified at concentrations above action levels in soil samples containing shot. No COCs were identified in soil samples that did not contain shot. A total of approximately 2.5 cubic yards $\left(\mathrm{yd}^{3}\right)$ of shot will be removed for disposal as hazardous waste (HW). Removal of shot will be verified by visual inspection, and the excavation will be backfilled with clean soil and contoured to the approximate surrounding topographic grade.

\subsubsection{Corrective Action Site 02-44-02, Paint Spills and French Drain}

This site is located in Area 2 at the former Painters' Shed, Paint Shop, and Paint Storage Rack. The site consists of two areas of paint spills and two french drains. Two areas of multiple layers of dried paint are present on the foundations of the former Paint Storage Rack and Painters' Shed. Chromium, lead, benzo(a)pyrene, benzo(b)floroanthene, and bis(2-ethylhexyl)phthalate were identified at concentrations above action levels in paint samples. The paint will be removed. The volume of paint is not expected to exceed 55 gallons (gal). Using the maximum theoretical leachate concentration, the paint exceeds Resource Conservation and Recovery Act (RCRA) toxicity characteristic concentrations for barium, chromium, and lead. Therefore, the paint will most likely require disposal as HW; however, waste characterization samples may be collected to confirm this disposal pathway.

The first french drain, a bottomless 55-gal drum, contained approximately 6 inches (in.) of soil with a thin layer of paint-like material on top. No COCs were identified in samples collected from the first french drain. The second french drain, a bottomless 55-gal drum embedded in the foundation of the former Painters' Shed, did not contain COCs. The two drain casings were removed and disposed during corrective action investigation activities.

Benzo(a)pyrene was identified at concentrations above the action level in one soil sample adjacent to the former Painters' Shed concrete foundation. Approximately $2 \mathrm{yd}^{3}$ of soil to a depth of 6 in. bgs will be removed. Using the maximum theoretical leachate concentration, the soil exceeds the RCRA toxicity characteristic concentrations for chromium and lead. Therefore, the soil will most likely require disposal as HW; however, waste characterization samples may be collected to confirm this disposal pathway.

A minimum of two verification samples, one from a randomly selected side wall and one from the floor of the excavation, will be collected and analyzed for benzo(a)pyrene. The number of verification samples may vary depending on the size of the final excavation. If verification sample results indicate that an action level is exceeded, additional soil will be removed, and additional verification samples will be collected. Upon verifying that the impacted soil has been removed, the excavation will be backfilled with clean soil and contoured to the approximate surrounding topographic grade.

As a BMP, asbestos tile will be removed from the concrete foundations of the former Paint Shop and Painters' Shed and within the immediate vicinity of the site. 


\subsubsection{Corrective Action Site 02-59-01, Septic System}

This site is located in Area 2 near a cable storage yard on the south side of Rainier Mesa Road and consists of a concrete septic tank approximately $30 \mathrm{ft}$ long and $6 \mathrm{ft}$ in diameter. Napthalene and 1,4-dichlorobenzene were identified at concentrations above action levels in a sludge sample collected from the septic tank. Approximately 4,200 gal of liquid and 550 gal of sludge will be removed from the septic tank and solidified using clean soil. The waste is expected to meet the permit requirements of the Area 9 U10c Sanitary Landfill. As a BMP, the septic tank will be removed, and the excavation will be backfilled with clean soil and contoured to the approximate surrounding topographic grade.

\subsubsection{Corrective Action Site 02-60-02, French Drain}

This site is located in Area 2 near the former Sheet Metal and Pipefitters' Shop and consisted of a french drain. The french drain was a rusted 55-gal drum with holes in the walls and bottom. Aroclor 1260 was identified at concentrations above the action level in one soil sample collected from the french drain. The impacted soil and french drain were removed and disposed during corrective action investigation activities. As a BMP, the drain grates and approximately $15 \mathrm{ft}$ of 2-in. steel drain piping will be removed.

\subsubsection{Corrective Action Site 02-60-03, Steam Cleaning Drain}

This site is located in Area 2 near the former Lineman's Shop and consists of a sump and an outfall pipe. As a BMP, the metal 3-in.-diameter outfall pipe will be removed. The sump is a shallow earthen pit with a steel grate cover. Benzo(a)pyrene was identified at concentrations above the action level in a soil sample collected from the sump. Approximately $16 \mathrm{yd}^{3}$ of soil to a depth of $3 \mathrm{ft}$ bgs will be removed from the sump. The waste is expected to meet the permit requirements of the Area 9 U10c Sanitary Landfill. As a BMP, the sump grate will be removed.

A minimum of two verification samples, one from a randomly selected side wall and one from the floor of the excavation, will be collected and analyzed for benzo(a)pyrene. The number of verification samples may vary depending on the size of the final excavation. If verification sample results indicate that an action level is exceeded, additional soil will be removed, and additional verification samples will be collected. Upon verifying that the impacted soil has been removed, the excavation will be backfilled with clean soil and contoured to the approximate surrounding topographic grade.

Aroclor 1260 was identified at concentrations above the action level in a soil sample collected near the southwest side of the sump. Approximately $10 \mathrm{yd}^{3}$ of soil to a depth of $1.5 \mathrm{ft}$ bgs will be removed. Using the maximum theoretical leachate concentration, the soil exceeds RCRA toxicity characteristic concentrations for cadmium. Therefore, the soil will most likely require disposal as HW; however, waste characterization samples may be collected to confirm this disposal pathway.

A minimum of two verification samples, one from a randomly selected side wall and one from the floor of the excavation, will be collected and analyzed for Aroclor 1260. The number of verification samples may vary depending on the size of the final excavation. If verification sample results indicate that an action level is exceeded, additional soil will be removed, and additional verification samples will be collected. Upon verifying that the impacted soil has been removed, the excavation will be backfilled with clean soil and contoured to the approximate surrounding topographic grade. 


\subsubsection{Corrective Action Site 02-60-04, French Drain}

This site is located in Area 2 near the Refrigeration Shop and consisted of a french drain. The french drain was a 10-in.-diameter, 9-ft-long perforated steel casing filled with pea gravel, sediment, and debris, located in the center of an 18-in.-thick reinforced concrete foundation. An area of the concrete foundation approximately 22 by $20 \mathrm{ft}$ was removed to allow for access to the drain during corrective action investigation activities. Benzo(a)pyrene, Aroclor 1260, and Aroclor 1268 were identified at concentrations above action levels in one sediment sample collected from the french drain. The sediment, drain casing, and concrete debris were removed and disposed during corrective action investigation activities. No COCs were identified in the soil surrounding the french drain.

\subsubsection{Corrective Action Site 02-60-05, French Drain}

This site is located in Area 2 at the former Operators' Office and the D-38 Storage Yard and consisted of a french drain. The french drain was a rusted and corroded bottomless 55-gal drum. The top 6 in. of the drum contained accumulated soil, and the rest of the drum was filled with leach rock. A layer of black tar-like material identified as chip seal is present throughout the area. The drain casing was removed and disposed during corrective action investigation activities.

Benzo(a)pyrene was identified at concentrations above the action level in a soil sample collected from the soil in the drum. Benzo(a)pyrene, benzo(a)anthracene, benzo(b)fluoranthene, benzo(k)fluoranthene, dibenzo(a,h)anthracene, and indeno(1,2,3-cd)pyrene were identified at concentrations above action levels in soil samples collected from the native soil below the drum and from the surrounding area. Approximately $48 \mathrm{yd}^{3}$ of soil to a depth of $15 \mathrm{ft}$ bgs will be removed from the former french drain and surrounding area. The waste is expected to meet the permit requirements of the Area 9 U10c Sanitary Landfill.

A minimum of two verification samples, one from a randomly selected side wall and one from the floor of the excavation, will be collected and analyzed for semi-volatile organic compounds (SVOCs). The number of verification samples may vary depending on the size of the final excavation. If verification sample results indicate that an action level is exceeded, additional soil will be removed, and additional verification samples will be collected. Upon verifying that the impacted soil has been removed, the excavation will be backfilled with clean soil and contoured to the approximate surrounding topographic grade.

\subsubsection{Corrective Action Site 23-60-01, Mud Trap Drain and Outfall}

This site is located in Area 23 near a wash shed in the former Defense Nuclear Agency compound. The site consists of a mud trap, grease rack, and outfall pipe. The mud trap is a concrete vault measuring 4 by 4 by $3.5 \mathrm{ft}$ with a metal grate cover that contained approximately $1.5 \mathrm{ft}$ of sediment and miscellaneous debris. The subsurface cast iron outfall pipe connects the mud trap to the outfall area just beyond the barbed-wire fence. The pipe is located at $2 \mathrm{ft}$ bgs.

Lead was identified at concentrations above the action level in sediment samples collected from the mud trap. Approximately $0.5 \mathrm{yd}^{3}$ of sediment will be removed from the mud trap. The sediment exceeds regulatory disposal criteria for lead. Therefore, the sediment will most likely require disposal as HW; however, waste characterization samples may be collected to confirm this disposal pathway. As a BMP, the mud trap and outfall pipe will be removed, and the excavation will be backfilled with clean soil and contoured to the approximate surrounding topographic grade. 


\subsubsection{Corrective Action Site 23-99-06, Grease Trap}

This site is located in Area 23 adjacent to Building 109 and consists of a grease trap. The trap is a concrete vault that is 3.5 by $2 \mathrm{ft}$ and $4 \mathrm{ft}$ deep. Aroclor 1260, chlordane, and arsenic were identified at concentrations above action levels in sediment samples collected from the grease trap. Approximately $0.5 \mathrm{yd}^{3}$ of sediment will be removed from the grease trap. The waste is expected to meet the permit requirements of the Area 9 U10c Sanitary Landfill. The grease trap will be backfilled with grout.

\subsubsection{Corrective Action Site 25-60-04, Building 3123 Outfalls}

This site is located in Area 25 near Building 3123 and consists of two outfalls referred to as Drain A and Drain B. The Drain A outfall pipe was previously removed. The Drain B outfall pipe is located at $1 \mathrm{ft}$ bgs and consists of approximately $50 \mathrm{ft}$ of 4-in. vitrified clay pipe with sludge contents.

Aroclor 1254 was identified at concentrations above the action level in soil samples collected to a depth of $2 \mathrm{ft}$ bgs and within $25 \mathrm{ft}$ laterally of the Drain B outfall. Approximately $30 \mathrm{yd}^{3}$ of soil to a depth of $3 \mathrm{ft}$ bgs will be removed from the outfall discharge area. The waste is expected to meet the permit requirements of the Area 9 U10c Sanitary Landfill. Lead and Aroclor 1254 were identified at concentrations above action levels in a sludge sample collected from the Drain B outfall pipe. The Drain B outfall pipe and approximately $0.25 \mathrm{yd}^{3}$ of sludge will be removed. Using the maximum theoretical leachate concentration, the sludge exceeds RCRA toxicity characteristic concentrations for RCRA metals and SVOCs. Therefore, the pipe and the sludge will most likely require disposal as HW; however, waste characterization samples may be collected to confirm this disposal pathway.

A minimum of two verification samples, one from a randomly selected side wall and one from the floor of the excavation, will be collected and analyzed for Aroclor 1254. The number of verification samples may vary depending on the size of the final excavation. If verification sample results indicate that an action level is exceeded, additional soil will be removed, and additional verification samples will be collected. Upon verifying that the impacted soil has been removed, the excavation will be backfilled with clean soil and contoured to the approximate surrounding topographic grade.

\subsection{CONSTRUCTION QUALITy ASSURANCE/QUALITY CONTROL}

No engineered structures will be constructed as part of site closure. Therefore, a construction quality assurance/quality control (QA/QC) plan is not required.

\subsubsection{Construction Field Sample Collection Activities}

Construction field samples are not required for closure of CAU 562. Sample collection activities for the purpose of waste stream characterization and to verify that cleanup criteria have been met are addressed in Section 2.4.

\subsubsection{Construction Laboratory/Analytical Data Quality Indicators}

Closure activities are limited to removal of contaminated material and debris. A construction QA/QC plan is not required, and construction data quality indicators are not applicable. 


\subsection{WASTE MANAGEMENT}

All waste streams will be managed and disposed according to applicable federal and state regulations and company waste management procedures. Closure activities are expected to generate sanitary waste and HW. Although not expected, if mixed waste (MW) and/or low-level waste (LLW) is generated, it will be properly managed and disposed. Confirmation of waste disposal will be included in the CAU 562 Closure Report (CR).

\subsubsection{Waste Minimization}

The volume of waste generated will be minimized to the maximum extent feasible. Waste will be properly characterized and segregated to avoid the generation of additional waste.

\subsubsection{Waste Types}

\subsubsection{Sanitary Waste}

Sanitary waste will be radiologically screened for free release (National Security Technologies, LLC, 2010) and disposed as sanitary waste in an onsite permitted landfill.

\subsubsection{Mixed Waste}

MW is waste containing both radioactive waste and HW constituents. Closure activities are not expected to generate MW; however, if generated, MW will be managed and disposed according to all applicable federal and state regulations and company waste management procedures. All MW will be packaged under the guidance of a Waste Certification Official and Waste Generator Services personnel. When staged on site, MW will be stored in a radioactive materials area and a 90-day HW accumulation area until a waste disposal profile is prepared and approved. Samples will be collected to enable completion of a treatability study, if necessary. The MW will then be disposed appropriately.

\subsubsection{Hazardous Waste}

Closure activities will most likely generate HW, which will be managed and disposed according to all applicable federal and state regulations and company waste management procedures. Upon generation, HW will be containerized and stored in a satellite accumulation area or a 90-day HW accumulation area, depending on the amount of waste generated. After an approved waste profile is generated, the waste will be disposed at a permitted offsite treatment, storage, and disposal facility.

\subsubsection{Low-Level Waste}

Closure activities are not expected to generate LLW; however, if generated, LLW will be managed and disposed according to all applicable federal and state regulations and company waste management procedures. All LLW will be packaged under the guidance of a Waste Certification Official and Waste Generator Services personnel. LLW will be stored in a radioactive materials area until a waste disposal profile is prepared and approved, and transport to an appropriate disposal facility can be arranged. 


\subsubsection{Decontamination Waste}

Equipment will be surveyed prior to release. Equipment that becomes contaminated will be decontaminated on site. Dry decontamination will be the preferred method. For larger pieces of equipment that cannot be effectively decontaminated using dry decontamination techniques, wet decontamination techniques will be used. Decontamination rinsate will be managed appropriately according to applicable regulations and, once characterized, properly disposed.

\subsubsection{Personal Protective Equipment}

All personal protective equipment that becomes contaminated during closure activities will be disposed with the appropriate waste stream.

\subsection{CONFIRMATION OF CORRECTIVE ACtions}

Accurate and defensible analytical data will be collected to verify that closure objectives are met. Confirmation of corrective actions will be included in the CR.

\subsubsection{Clean Closure Sites}

The following sections describe the activities that will be performed to confirm the completion of corrective actions. A summary of verification sample collection is provided in Table 2.

TABle 2. Verification SAMPle Methods AND ACTION LeVelS

\begin{tabular}{|c|c|c|c|}
\hline Corrective Action Site & Analysis & Action Level & Analytical Method \\
\hline 02-44-02, Paint Spills and French Drain & Benzo(a)pyrene & $0.21 \mathrm{mg} / \mathrm{kg}$ & EPA SW-846 8270 \\
\hline \multirow{2}{*}{ 02-60-03, Steam Cleaning Drain } & Benzo(a)pyrene & $0.21 \mathrm{mg} / \mathrm{kg}$ & EPA SW-846 8270 \\
\hline & Aroclor 1260 & $0.74 \mathrm{mg} / \mathrm{kg}$ & EPA SW-846 8082 \\
\hline \multirow{6}{*}{ 02-60-05, French Drain } & Benzo(a)pyrene & $0.21 \mathrm{mg} / \mathrm{kg}$ & \multirow{6}{*}{ EPA SW-846 8270} \\
\hline & Benzo(a)anthracene & $2.1 \mathrm{mg} / \mathrm{kg}$ & \\
\hline & Benzo(b)fluoranthene & $2.1 \mathrm{mg} / \mathrm{kg}$ & \\
\hline & Benzo(k)fluoranthene & $21 \mathrm{mg} / \mathrm{kg}$ & \\
\hline & Dibenzo(a,h)anthracene & $0.21 \mathrm{mg} / \mathrm{kg}$ & \\
\hline & Indeno(1,2,3-cd)pyrene & $2.1 \mathrm{mg} / \mathrm{kg}$ & \\
\hline 25-60-04, Building 3123 Outfalls & Aroclor 1254 & $0.74 \mathrm{mg} / \mathrm{kg}$ & EPA SW-846 8082 \\
\hline
\end{tabular}

\subsubsection{Corrective Action Site 02-26-11, Lead Shot}

Removal of shot will be verified by visual inspection and photographic documentation. Verification samples are not required at this site.

\subsubsection{Corrective Action Site 02-44-02, Paint Spills and French Drain}

Removal of paint and asbestos tile will be verified by visual inspection and photographic documentation. Removal of soil contaminated with benzo(a)pyrene will be verified by confirming that laboratory results for verification samples are below action levels. A minimum of two verification samples will be collected from the excavation and analyzed for benzo(a)pyrene using U.S. Environmental Protection Agency (EPA) method SW-846 8270 (EPA, 2008). The action level for benzo(a)pyrene is 0.21 milligrams per kilogram (mg/kg). 


\subsubsection{Corrective Action Site 02-59-01, Septic System}

Removal of the septic tank will be verified by photographic documentation. Verification samples are not required at this site.

\subsubsection{Corrective Action Site 02-60-02, French Drain}

Removal of contaminated soil was completed during corrective action investigation activities. Removal of the drain grates and drain pipe will be verified by photographic documentation. Verification samples are not required at this site.

\subsubsection{Corrective Action Site 02-60-03, Steam Cleaning Drain}

Removal of the outfall pipe will be verified by photographic documentation. Removal of soil contaminated with benzo(a)pyrene will be verified by confirming that laboratory results for verification samples are below action levels. A minimum of two verification samples will be collected from the excavation and analyzed for benzo(a)pyrene using EPA method SW-846 8270 (EPA, 2008). The action level for benzo(a)pyrene is $0.21 \mathrm{mg} / \mathrm{kg}$. Removal of soil contaminated with Aroclor 1260 will be verified by confirming that laboratory results for verification samples are below action levels. A minimum of two verification samples will be collected from the excavation and analyzed for Aroclor 1260 using EPA method SW-846 8082 (EPA, 2008). The action level for Aroclor 1260 is $0.74 \mathrm{mg} / \mathrm{kg}$.

\subsubsection{Corrective Action Site 02-60-04, French Drain}

Removal of contaminated sediment was completed during corrective action investigation activities. Verification samples are not required at this site.

\subsubsection{Corrective Action Site 02-60-05, French Drain}

Removal of soil contaminated with SVOCs will be verified by confirming that laboratory results for verification samples are below action levels. A minimum of two verification samples will be collected from the excavation and analyzed for SVOCs using EPA method SW-846 8270 (EPA, 2008). The action levels for the SVOCs of concern are listed in Table 2.

\subsubsection{Corrective Action Site 23-60-01, Mud Trap Drain and Outfall}

Removal of the mud trap and outfall pipe will be verified by photographic documentation. Verification samples are not required at this site.

\subsubsection{Corrective Action Site 23-99-06, Grease Trap}

Backfilling the grease trap with grout will be verified by photographic documentation. Verification samples are not required at this site.

\subsubsection{Corrective Action Site 25-60-04, Building 3123 Outfalls}

Removal of the outfall pipe will be verified by photographic documentation. Removal of soil contaminated with Aroclor 1254 will be verified by confirming that laboratory results for verification samples are below action levels. A minimum of two verification samples will be collected from the excavation and analyzed for Aroclor 1254 using EPA method SW-846 8082 (EPA, 2008). The action level for Aroclor 1254 is $0.74 \mathrm{mg} / \mathrm{kg}$. 


\subsubsection{Sample Collection Methods}

Verification samples will be collected using standard sampling procedures. Collection date, time, and other pertinent information will be logged on a "Service Request and Chain of Custody Record,” and recorded in a bound notebook. Samples will be collected by hand using disposable sampling equipment and placed in clean containers, labeled with unique sample identification numbers using the CAS number followed by the sample number (e.g., 02-44-02-V1), sealed with a tamper-proof seal, bagged, placed on ice, and transported to an offsite laboratory following strict chain of custody. Samples will be analyzed by EPA-approved methods at EPA-approved laboratories (EPA, 1996). Sample analysis will follow stringent QA/QC procedures (EPA, 1996). Analysis for radioisotopes will be performed in accordance with The Procedures Manual of the Environmental Measurements Laboratory (U.S. Department of Energy, 1997).

One set of QA/QC samples will be collected for every 20 environmental samples or with every batch of samples submitted for laboratory analysis, whichever is greater, and will include blind duplicates, matrix spike/matrix spike duplicates, and equipment rinsate samples. All blind duplicates will be labeled with a unique sample number. All samples will be collected according to the Industrial Sites Quality Assurance Project Plan (U.S. Department of Energy, National Nuclear Security Administration Nevada Operations Office [NNSA/NV], 2002).

\subsubsection{Laboratory/Analytical Data Quality Indicators}

Verification samples will be collected and analyzed to confirm the completion of corrective actions, and waste characterization samples may be collected for disposal purposes. All data will be reviewed to ensure the data are usable and complete according to the Industrial Sites Quality Assurance Project Plan (NNSA/NV, 2002). 100 percent of data packages will be evaluated at the Tier I and Tier II levels. Any data determined to not be valid will be identified in the CR.

Data quality indicators are qualitative and quantitative statements that specify the data requirements of a project and include precision, accuracy, representativeness, comparability, completeness, and sensitivity. The data quality indicators are discussed below.

\subsubsection{Precision}

Precision is a measure of agreement among a replicate set of measurements of the same property under similar conditions. This agreement is expressed as the relative percentage difference (RPD) between duplicate measurements. Precision applies to parameters sampled and analyzed in duplicate. One duplicate sample will be collected per set of verification samples. All duplicate samples will be collected from the same medium and analyzed for the same set of analytes. The precision of the analytical results will be assessed by calculating the RPD for a verification sample and its duplicate sample results. An RPD of less than or equal to 30 percent indicates acceptable precision (NNSA/NV, 2002).

\subsubsection{Accuracy}

Accuracy is a measure of the closeness of an individual measurement or the average of a number of measurements to the true value. Accuracy includes a combination of random error (precision) and systematic error (bias) components that result from sampling and analytical operations. This closeness is expressed as percent recovery (\%R). Accuracy will be assessed by examining the \%R of laboratory control and spiked samples. A \%R within the range of 70 to 130 percent indicates satisfactory analytical accuracy (NNSA/NV, 2002). 


\subsubsection{Representativeness}

Representativeness is a qualitative evaluation of measurement system performance. It is the degree to which sample data accurately and precisely represent a characteristic of a population, parameter variations at a sampling point, or an environmental condition. Representativeness will be attained by ensuring that the sample locations, analytical parameters, analytical methods, sampling protocols, and sample handling all meet the project-specific objectives.

\subsubsection{Comparability}

Comparability is a qualitative measure that expresses the confidence that one data set can be compared to another. It will be achieved by using standardized field sampling procedures. The same analytical laboratory will perform the analyses for all samples. Sample results will be reported in standard units to allow for comparison of the data.

\subsubsection{Completeness}

Completeness is a quantitative measure of data quality expressed as the percentage of valid data obtained that satisfies the project-specific requirements. Since a limited number of samples will be collected for both waste characterization and verification of closure, 100 percent of the data collected needs to be of acceptable quality to maintain acceptable QA/QC standards.

\subsubsection{Sensitivity}

Sensitivity is the capability of a method or instrument to discriminate between measurement responses representing different levels of a variable of interest. This indicator is determined from the value of the standard deviation at the concentration level of interest. It represents the minimum difference of concentration that can be distinguished between two samples with a high degree of confidence. Sensitivity must be sufficient to detect contaminants at or below decision levels. Sensitivity will be achieved by analyzing all samples using appropriate EPA-approved analytical laboratories, methods, and instruments.

\subsection{Permits}

Prior to beginning closure activities, planning documents and permits will be prepared. These documents will include a National Environmental Policy Act Checklist, a Real Estate/Operations Permit, Radiological Work Permits (RWPs), excavation permits, and blind penetration permits.

\subsubsection{National Environmental Policy Act Checklist}

A National Environmental Policy Act Checklist will be completed prior to all closure activities at the site. Closure activities will follow all applicable federal, state, and local laws, regulations, and permits regarding protection of the environment.

\subsubsection{Real Estate/Operations Permit}

A Real Estate/Operations Permit will be obtained prior to beginning closure activities. The permit will establish NNSA/NSO as the prime authority possessing control of the site. 


\subsubsection{Radiological Work Permit}

An RWP will be required for work at any radiologically impacted site when radiological conditions require, as determined by a Health Physicist. The RWP will inform workers of the specific personal protective equipment required and identify site-specific controls. Workers will be required to sign the RWP and acknowledge their understanding of the requirements before entry into any radiologically controlled area. The RWP will be maintained by the Radiological Control Technician at the entrance to the radiologically controlled area. All site workers will be required to be Radiation Worker II-trained to perform work within a radiologically controlled area.

\subsubsection{Utility Clearances, Excavation Permits, and Blind Penetration Permits}

An excavation permit and a blind penetration permit will be obtained prior to beginning excavation activities. These permits require that a utility clearance be performed. A copy of the permit will be filed on site throughout the duration of the project. 
CAU 562 CAP

Section: Detailed SOW

Revision: 0

Date: April 2011

THIS PAGE INTENTIONALLY LEFT BLANK 


\subsection{SCHEDULE}

All preparation and field activities are scheduled for completion in fiscal year 2012. Sufficient flexibility will be incorporated into the field schedule to allow for minor difficulties (e.g., weather, equipment failure). NNSA/NSO shall notify the Nevada Division of Environmental Protection of any condition or event that may impact the project schedule. 
Revision: 0

Date: April 2011

THIS PAGE INTENTIONALLY LEFT BLANK 


\subsection{POST-CLOSURE PLAN}

None of the CASs in CAU 562 will be closed in place with administrative controls. Use restrictions will not be implemented, and post-closure inspections will not be required.

\subsection{INSPECTIONS}

Post-closure inspections will not be required for CAU 562.

\subsection{MONITORING}

Post-closure monitoring will not be required for CAU 562.

\subsection{MAINTENANCE AND REPAIR}

Post-closure maintenance and repair will not be required for CAU 562. 
CAU 562 CAP

Section: Post-Closure Plan

Revision: 0

Date: April 2011

THIS PAGE INTENTIONALLY LEFT BLANK 


\subsection{REFERENCES}

EPA, see U.S. Environmental Protection Agency.

Federal Facility Agreement and Consent Order. 1996 (as amended March 2010). Agreed to by the State of Nevada; the U.S. Department of Energy, Environmental Management; the U.S. Department of Defense; and the U.S. Department of Energy, Legacy Management.

NNSA/NSO, see U.S. Department of Energy, National Nuclear Security Administration Nevada Site Office.

NNSA/NV, see U.S. Department of Energy, National Nuclear Security Administration Nevada Operations Office.

U.S. Department of Energy. 1997. The Procedures Manual of the Environmental Measurements Laboratory, HASL-300, $28^{\text {th }}$ Ed., Vol. 1. New York, NY.

U.S. Department of Energy, National Nuclear Security Administration Nevada Operations Office. 2002. Industrial Sites Quality Assurance Project Plan, Nevada Test Site, Nevada, Revision 3, DOE/NV--372. Las Vegas, NV.

U.S. Department of Energy, National Nuclear Security Administration Nevada Site Office. 2009. Corrective Action Investigation Plan for Corrective Action Unit 562: Waste Systems, Nevada Test Site, Nevada, DOE/NV--1317. Las Vegas, NV.

U.S. Department of Energy, National Nuclear Security Administration Nevada Site Office. 2010. Corrective Action Decision Document for Corrective Action Unit 562: Waste Systems, Nevada Test Site, Nevada, DOE/NV--1396. Las Vegas, NV.

National Security Technologies, LLC. 2010. Nevada Test Site Radiological Control Manual, DOE/NV/25946--801. Las Vegas, NV.

U.S. Environmental Protection Agency. 1996. Test Methods for Evaluating Solid Waste Physical/Chemical Methods, SW-846, Third Edition. Washington, D.C. 
CAU 562 CAP

Section: References

Revision: 0

Date: April 2011

THIS PAGE INTENTIONALLY LEFT BLANK 


\section{APPENDiX A.1}

\section{ENGINEERING SPECIFICATION AND DRAWINGS}

NOTE: Engineering specifications and drawings are not required for closure of Corrective Action Unit 562. This Appendix is included as required by the approved Federal Facility Agreement and Consent Order outline for a Corrective Action Plan.

\section{A.1-1}


CAU 562 CAP

Section: Appendix A.1

Revision: 0

Date: April 2011

THIS PAGE INTENTIONALLY LEFT BLANK

A.1-2 


\section{ApPendix A.2}

\section{SAMPling AND ANALysis Plan}

NOTE: Sufficient details on the type, number, and location of verification samples to be collected to verify site closure activities have been provided in Sections 2.1.2 and 2.4 of this document. This Appendix is included as required by the approved Federal Facility Agreement and Consent Order outline for a Corrective Action Plan. 
CAU 562 CAP

Section: Appendix A.2

Revision: 0

Date: April 2011

THIS PAGE INTENTIONALLY LEFT BLANK 
Revision: 0

Date: April 2011

\section{Appendix A.3}

\section{Project Organization}


CAU 562 CAP

Section: Appendix A.3

Revision: 0

Date: April 2011

THIS PAGE INTENTIONALLY LEFT BLANK

A.3-2 
For this project, the U.S. Department of Energy, National Nuclear Security Administration Nevada Site Office (NNSA/NSO) points of contact are as follows:

NNSA/NSO Federal Industrial Sites Sub-Project Director: Kevin J. Cabble

Telephone Number: (702) 295-5000

NNSA/NSO Task Manager: Tiffany Lantow

Telephone Number: (702) 295-7645

The identification of the project Health and Safety Officer and the Quality Assurance Officer can be found in the appropriate plan. However, personnel are subject to change, and it is suggested that the appropriate U.S. Department of Energy Federal Sub-Project Director be contacted for further information. 
CAU 562 CAP

Section: Appendix A.3

Revision: 0

Date: April 2011

THIS PAGE INTENTIONALLY LEFT BLANK 
CAU 562 CAP

Section: Library Distribution List

Revision: 0

Date: April 2011

\section{LIBRARY DISTRIBUTION LIST}


CAU 562 CAP

Section: Library Distribution List

Revision: 0

Date: April 2011

\section{THIS PAGE INTENTIONALLY LEFT BLANK}


U.S. Department of Energy

National Nuclear Security Administration

Nevada Site Office

Technical Library

P.O. Box 98518, M/S 505

Las Vegas, NV 89193-8518

U.S. Department of Energy

Office of Scientific and Technical Information

P.O. Box 62

Oak Ridge, TN 37831-0062

Southern Nevada Public Reading Facility

c/o Nuclear Testing Archive

P.O. Box 98521, M/S 400

Las Vegas, NV 89193-8521

Manager, Northern Nevada FFACO

Public Reading Facility

c/o Nevada State Library \& Archives

Carson City, NV 89701-4285
1 (Uncontrolled, electronic copy)

1 (Uncontrolled, electronic copy)

2 (Uncontrolled, electronic copies)

1 (Uncontrolled, electronic copy) 
CAU 562 CAP

Section: Library Distribution List

Revision: 0

Date: April 2011

\section{THIS PAGE INTENTIONALLY LEFT BLANK}

